\title{
Justiça e Ditadura: atuação das Cortes Supremas de Brasil e Argentina durante as ditaduras de segurança nacional
}

\author{
Patricia da Costa Machado \\ Universidade Federal do Rio Grande do Sul
}

\section{Introdução}

O século XX foi uma época de extremos, como bem definiu Eric Hobsbawm. Na América Latina, com raras exceções, foi caracterizado por longos períodos de governos autoritários e ditaduras, alternados com breves períodos de democracia. Durante um período de quase quatro décadas, a maioria das nações latino-americanas vivenciaram ditaduras de segurança nacional ${ }^{1}$. As diferentes experiências em cada um dos diversos países que compõem a região possuem elos em comum: a tomada do poder pelas Forças Armadas, a aplicação da Doutrina de Segurança Nacional (DSN) ${ }^{2}$, a suspensão de direitos e garantias fundamentais e o consequente estabelecimento do Terrorismo de Estado (TDE).

As ditaduras da segunda metade do século XX do Cone $\mathrm{Sul}^{3}$ apresentam uma série de evidências que permitem afirmar que todas utilizaram o terror como forma de repressão política, direcionado não apenas aos dissidentes, mas à população em geral, através de métodos como o desaparecimento, a tortura, a prisão, a censura. Buscando consolidar os regimes através do uso da força, todos utilizaram o direito e o judiciário para aplicar ou acobertar os crimes resultantes dessas políticas repressivas.

$\mathrm{O}$ artigo tem como objetivo analisar, através de decisões judiciais e legislação concernente ao papel das Cortes Supremas de Brasil e Argentina, o posicionamento destes tribunais frente à ruptura democrática vivenciada nesses países a partir dos golpes de 1 de abril de 1964 e de 24 de março de 1976, buscando compreender a relação dialética entre o Judiciário e a repressão que foi implementada nos anos que se seguiram ${ }^{4}$. A escolha pelos dois países está relacionada ao fato de que se encontram em polos distintos no quesito de responsabilização criminal de agentes acusados de violar direitos humanos durante o período: enquanto no Brasil a Lei da Anistia permanece como barreira jurídica e a atual situação política cause um revisionismo quanto ao próprio período da ditadura, na Argentina o processo de juicios de crimes de lesa humanidade permanece sendo levado a cabo, mesmo após a eleição de um governo não alinhado a pautas de direitos humanos. Buscando

\footnotetext{
${ }^{1}$ Este trabalho se insere a uma extensa lista de análises que conceituam as ditaduras latino-americanas como ditaduras de segurança nacional. Por esse motivo, não iremos aprofundar os debates conceituais, esmiuçados em: Padrós (2005), Bauer (2011) e Gasparotto (2016).

${ }^{2}$ A Doutrina de Segurança Nacional (DSN), elaborada pelos EUA no pós-guerra e readaptada nos países em questão, parte do princípio de que a nação, seus valores, símbolos e deveres está ameaçada por forças subversivas e considera como inimigo interno qualquer forma de pensamento crítico e questionador do status quo. Para a DSN, há dois tipos de inimigos: o interno e o externo.

${ }^{3}$ O Cone Sul é uma região geográfica que engloba a parte sul da América do Sul. Embora não haja consenso, é comum apontar que fazem parte dessa região Brasil, Argentina, Chile, Uruguai, Paraguai e Bolívia.

${ }^{4} \mathrm{O}$ presente artigo é decorrente de pesquisa de doutorado em andamento, que busca compreender a atuação das Cortes Supremas dos cinco países do Cone Sul.
} 
entender o cenário atual, necessário analisar como se posicionaram os tribunais superiores durante as ditaduras, buscando compreender as rupturas e continuidades presentes nessas instituições ${ }^{5}$.

$\mathrm{O}$ arcabouço teórico do artigo se sustenta na perspectiva da história do direito, um conceito abrangente que inclui regras, normas sociais sancionadas por autoridades, dentro de um sistema preciso de coerções e punições e que exige uma delimitação clara de suas fronteiras. Partimos da produção historiográfica e teórica de Edward Thompson, já que o elemento central de sua abordagem é a distinção de três aspectos diferenciados na lei: a instituição (e aqueles que a exercem), a ideologia e o código, com lógica e procedimentos próprios (a lei enquanto lei). A lei enquanto prática, portanto, não se localiza em uma distante superestrutura, mas perpassa as próprias relações como norma endossada pela comunidade (Thompson, 1987, p. 353-354). Por outro lado, ao invés de mecanismo de consenso, constitui-se no próprio campo onde o conflito social se desenvolve. Em suas palavras:

É inerente ao caráter específico da lei, como corpo de regras e procedimentos, que aplique critérios lógicos referidos a padrões de universalidade e igualdade. Mas, se um excesso disso for verdade, as consequências serão francamente contraproducentes. A maioria dos homens tem um forte senso de justiça, pelo menos em relação aos seus próprios interesses. Se a lei é manifestamente parcial e injusta, não vai mascarar nada, legitimar nada, contribuir em nada para a hegemonia de classe alguma (Thompson, 1987, p. 354).

No que diz respeito ao período das ditaduras, a comparação como metodologia para compreender as similaridades e diferenças é explicada não apenas por questões geográficas, mas pelas proximidades históricas e políticas, uma vez que possuem em comum o contexto histórico da Guerra Fria e a disputa ideológica e política entre as duas grandes superpotências. Durante os mais de quarenta anos em que perdurou, não houve conflito bélico direto entre Estados Unidos e União Soviética; contudo, as mais diversas regiões do planeta sofreram os impactos da disputa por zonas de influência, o que trouxe consequências para países que enfrentavam mazelas próprias, decorrente das desigualdades sociais produzidas por séculos de colonialismo e do sistema capitalista. A América Latina, considerada "quintal" dos Estados Unidos, sofreu diretamente com este jogo de poder, o que explica, pelo menos em parte, os elos entre os regimes ditatoriais da região.

O recorte temporal diverge por questões próprias de cada contexto. A análise do caso brasileiro terá como marco o período compreendido entre o golpe de 1964 a edição do Ato Institucional n. 5, já que, após dezembro de 1968, o Supremo Tribunal Federal perdeu o protagonismo do ordenamento jurídico nacional, uma vez que a garantia do habeas corpus para casos de crimes políticos foi suspensa. No caso argentino, o recorte abrange de 1976 (data do golpe)

\footnotetext{
${ }^{5}$ A atuação do Judiciário brasileiro, em especial do STF, sempre foi refrataria à aplicação de legislação internacional no que diz respeito aos crimes da ditadura, diferentemente do que ocorre na Argentina. Para além disso, e necessário apontar que os diferentes rumos tomados já em período democrático são mais complexos e não se explicam apenas pela via jurídica. A forte atuação dos movimentos de direitos humanos argentinos, bem como o posicionamento de parte da classe política sobre o tema e o posicionamento da sociedade civil, ajudam a explicar os motivos pelos quais mesmo com a chegada de Mauricio Macri ao poder, em 2016, os retrocessos foram poucos. Mesmo políticos alinhados à direita não se posicionam abertamente favoráveis a ditadura militar, diferente do Brasil, que tem desde janeiro de 2019 Jair Bolsonaro como presidente da República, que demonstra admiração ao período da ditadura e a figuras como Carlos Brilhante Ustra e Augusto Pinochet.
} 
a 1983, pois foi somente no final da ditadura que a Corte passou a impor certos limites à repressão estatal. Partindo dessa perspectiva comparativa, analisaremos o papel das Cortes Supremas argentina e brasileira durante as ditaduras.

\section{O Supremo Tribunal Federal e a ditadura (1964-1968)}

\subsection{O ordenamento jurídico e a configuração da Corte Suprema: do golpe ao AI-5}

Segundo pesquisa desenvolvida pelo cientista político Anthony W. Pereira em seu estudo comparativo sobre o fenômeno denominado judicialização da repressão, o Brasil foi o país que mais fez uso da combinação entre poder de fato e de direito. Segundo este autor, as diferentes características dos sistemas legais são moldadas, em parte, pela história de cooperação e do antagonismo existente entre duas organizações estatais: o alto oficialato das Forças Armadas e o poder judiciário (Pereira, 2010, p. 26).

O relatório da Comissão Nacional da Verdade (CNV), publicado em dezembro de 2014, analisou o papel do Judiciário durante a ditadura e apontou que, embora a responsabilidade do Estado pela ocorrência de graves violações aos direitos humanos tenha decorrido principalmente de ações ou omissões do Poder Executivo, o Judiciário exerceu importante função na estrutura repressiva, uma vez que sua atribuição constitucional era - e permanece sendo - examinar, nos casos concretos, situações dessa natureza. Em seu capítulo 17 (CNV, 2014), o relatório analisa quatro eixos principais: a atuação do STF entre 1964 e 1968, de 1968 em diante (após a edição do AI-5), da Justiça Militar (JM) e da Justiça Comum (Estadual e Federal). Para fins deste artigo, focaremos no período entre 1964 e 1968, uma vez que após a edição do AI-5 o Supremo Tribunal Federal passa a atuar como coadjuvante no ordenamento jurídico brasileiro.

A ênfase na legalidade, ainda que construída de forma casuística, e a consequente preservação do Judiciário em funcionamento, embora tolhido e supervisionado pelo poder militar, se explicam pela própria natureza do regime ditatorial. Nesse sentido, aponta Otavio Valério que:

A obsessão do executivo militar de 1964 em vestir seus atos de legalidade não passou despercebida. É possível apontar ao menos três fatores que contribuíram de forma preponderante para esta obsessão. O primeiro é a hierarquia e a formação rígida, características das Forças Armadas. O respeito à ordem, traduzido na obediência à cadeia de comando, é talvez o valor fundamental dos militares. Em tempos de guerra, não há espaço para debates; a ordem deve ser dada e imediatamente cumprida, ou pessoas podem morrer. $\mathrm{O}$ adestramento da conduta militar é regido pela estrita obediência às regras internas da corporação, e a vida no quartel é totalmente pautada por regulamentos e manuais de procedimentos. A pirâmide hierárquica militar certamente é o que mais se aproxima da ideia kelsiana de hierarquia das normas jurídicas. Do general ao soldado, recebia a ordem de um militar hierarquicamente superior, ela não pode ser questionada e deve ser simplesmente cumprida (há poucas exceções para casos muito específicos). Daí o apreço dos militares pelas regras de direito: uma vez que a norma esteja inserida no "sistema jurídico militar", a hierarquia se encarrega de seu devido cumprimento (Valério, 2010, p. 74). 
Durante a ditadura, o Supremo Tribunal Federal foi vital para a manutenção do regime, papel que ficou estabelecido de maneira contundente logo após o golpe, com a participação do presidente da Corte, ministro Álvaro Moutinho Ribeiro da Costa, à posse (inconstitucional) de Ranieri Mazzili no cargo de Presidente. Sobre a atuação do Supremo nesse período, Valério aponta para o fato de que:

se o STF não se envolveu nem apoiou a conspiração civil-militar que derrubou Goulart, é certo que boa parte de seus membros aplaudiu a queda do presidente. O presidente do Supremo, Ribeiro da Costa, abertamente defendeu o golpe, admitindo inclusive que "a sobrevivência da democracia se há de fazer, nos momentos de crise, com o sacrifício transitório de alguns de seus princípios e garantias constitucionais". O ministro Villa Lobos saudou o "vitorioso movimento anticomunista [...] de bravos soldados". O ministro Aliomar Baleeiro, alguns anos depois, escrevera que "em 1964, houve idílio inicial entre a Revolução e o Supremo". O ministro Pedro Chaves recebeu "a Revolução de 31 de março como uma manifestação da providência divina em benefício da nossa Pátria. Não me mantive em atitude contemplativa. Tive a coragem de alertar a Nação, em discurso de 11 de agosto de 1962, para o desfiladeiro tenebroso a que estávamos sendo conduzidos" (Valério, 2010, p. 49).

A ordem jurídica da ditadura inicialmente era híbrida, pois a Constituição democrática de 1946 não foi revogada, sendo complementada pelos atos institucionais, que passaram a ser a forma predominante de legislação utilizada pelo Poder Executivo. O Ato Institucional n. 1 considerava que "a revolução" se legitimava por si própria, afastando a relevância da participação do Legislativo ou de qualquer outra instância política.

Com o advento do Ato Institucional n. 2 em outubro de 1965, as restrições aos poderes do Judiciário foram formalizadas: as garantias constitucionais e legais de vitaliciedade e estabilidade foram suspensas por seis meses, e tornou-se possível aposentar ou demitir, por decreto presidencial, servidores federais, rol que incluía os membros da magistratura.

O AI-2 também aumentou o número de ministros do Supremo de 11 par 16, o que resultou na indicação de magistrados mais alinhados ao regime. A intervenção atingiu diretamente a estrutura do Judiciário: a competência da Justiça Militar sobre os civis foi ampliada aos crimes contra a segurança nacional ou às instituições militares; estabeleceu-se que essa competência deveria prevalecer sobre qualquer outra definida em leis ordinárias; impôs-se o julgamento prévio, pelo Superior Tribunal Militar (STM), dos habeas corpus (HC) impetrados pelos acusados desses crimes; e o foro privilegiado de governadores de estado e de seus secretários foi extinto.

A edição do AI-2 foi, em parte, resultado da atuação do STF nos julgamentos de habeas que tinham como objeto o questionamento da competência da justiça militar para julgar crimes políticos ${ }^{6}$. Em decorrência dessa atuação, moderada porém importante, cada decisão em favor dos presos políticos era recebida por setores da ditadura como uma provocação. Segundo Maria Helena

\footnotetext{
${ }^{6}$ Necessário apontar para o fato de que não havia (e ainda não há), no ordenamento jurídico brasileiro, uma definição de crime político. Apesar de a Constituição de 1988 estabelecer a competência da Justiça Federal para processar e julgar os crimes políticos (art. 109, IV, da CR/1988), não há, na própria Constituição ou na legislação infraconstitucional, uma definição de crime político, a não ser de maneira ampla e propositadamente aberta, como na Lei da Anistia.
} 
Moreira Alves, assim se estabeleceu um confronto entre a estrutura legal tradicional e a estrutura paralela extralegal, pois os coronéis dos IPMs passaram a protestar com indignação cada vez maior contra a autonomia judicial, forçando o Executivo a ampliar as medidas de controle sobre os juízes e o próprio judiciário (Moreira Alves, 1987, p. 57).

Em 7 de dezembro de 1966, foi editado o Ato Institucional n. 4, que teve como objetivo a convocação do Congresso Nacional para reunião extraordinária, visando a discussão, votação e promulgação do projeto de Constituição apresentado pelo presidente. Desse modo, a Constituição de 1946 finalmente chegaria ao seu fim, dando espaço à constituição outorgada de 1967, que novamente modificou a estrutura do Judiciário. Verifica-se, portanto, que o ordenamento jurídico montado pela ditadura, ao subordinar os demais poderes ao Executivo e ao restringir o controle dos atos institucionais e o exercício dos direitos e garantias fundamentais, acabou por modificar de maneira irreversível a separação de poderes.

Por sua vez, o Ato Institucional n. 5, datado de 13 de dezembro de 1968, embora declarasse mantidas a Constituição de 1967 e as constituições estaduais, estabelecia regras em flagrante violação a elas. No que diz respeito ao acesso ao Judiciário, o principal impacto foi a suspensão da garantia de habeas corpus nos crimes mencionados em seu artigo 10, que ratificou a exclusão já expressa nos atos institucionais anteriores, de apreciação judicial de todos os atos praticados de acordo com referido ato institucional e seus atos complementares. Ademais, o AI-5 permitiu que o presidente da República interferisse diretamente na composição do Judiciário, dando ensejo à edição do decreto de janeiro de 1969 que aposentou compulsoriamente os ministros Evandro Lins e Silva, Hermes Lima e Victor Nunes Leal, ao que seguiu a saída voluntária do então presidente do tribunal, Antônio Gonçalves de Oliveira, bem como do ministro Antônio Carlos Lafayette de Andrada (CNV, 2014, p. 938).

Quais os motivos para que, em pouco mais de quatro anos, o governo militar passasse a intervir de maneira tão enfática na Corte Suprema brasileira? A explicação reside na moderada atuação dos ministros do Supremo entre os anos de 1964 e 1968, como veremos.

\subsection{O posicionamento do Supremo Tribunal Federal entre 1964 e 1968}

No que diz respeito ao posicionamento da Suprema Corte brasileiro ao longo dos 21 anos em que durou a ditadura, pode-se dizer que o tribunal foi levado a pronunciar-se a respeito de graves violações de direitos humanos por meio de recursos ordinários e criminais e, principalmente, de pedidos de habeas corpus (HC), que foram o principal recurso utilizado por advogados de vítimas entre 1964 e 1968 (CNV, 2014, p. 935).

Entre 1964 e 1968, o Supremo utilizou alguns critérios para conceder pedidos feitos por presos políticos: após algumas discussões iniciais, os ministros passaram a desconsiderar como critério o fato de a autoridade coatora ser ou não militar, mas sim se a natureza do delito fazia incidir os casos previstos como crimes políticos ou contra a segurança nacional. Ademais, o tempo de duração da prisão, que tinha como limite o prazo de 60 dias, foi fator relevante considerado pelos magistrados ao analisarem os pedidos, uma vez que o prazo raramente era cumprido e casos de pessoas presas há meses eram comuns de chegar à Corte. Por fim, a existência de lei específica mais benéfica ao impetrante e a existência de foro privilegiado (vários governadores conseguiram habeas 
para serem julgados pelas Assembleias Legislativas estaduais) também eram considerados nos votos dos ministros.

Ainda em 1964, quando vigorava apenas o AI-1, o STF inaugurou um período marcado por sucessivas concessões de habeas corpus em favor de civis acusados de crimes contra a segurança nacional, tendo em vista as irregularidades verificadas nos inquéritos policiais militares. $\mathrm{O}$ julgamento do Habeas Corpus (HC) n. 41.879 ilustra bem o posicionamento nesses primeiros anos de ditadura. Julgado em 17 de março de 1965, tinha como objeto o pedido de Mario Roriz Soares de Carvalho, indiciado em Inquérito Policial Militar (IPM) em Goiás, pelo cometimento de suposto crime contra a segurança nacional. Diante da iminência de ser processado, recorreu ao Supremo, alegando a incompetência da Justiça Militar e a inexistência de crime e de provas de sua autoria. O ministro relator Hermes Lima defendeu que o STF não era competente para julgar o habeas, enquanto Evandro Lis afirmou que o entendimento da questão passaria pela análise do suposto crime cometido: o ato imputado seria o de ter proferido, como orador da sua turma da Faculdade de Direito, discurso "violento de conteúdo ideológico".

O ministro Martins Villas Boas em seu voto afirmou o seguinte:

Esse bacharel, quando estudante, teria tido essas ideias. Já formado, continuava a professa-las. Não acho que ninguém deve ser processado e condenado pelas ideias que professa. São necessários atos positivos, ou seja, que o individuo tente mudar a ordem política e social mediante ajuda de estado estrangeiro ou de caráter internacional. Pensar desta ou daquela forma não é crime. Quando a pessoa dá corpo a esse pensamento, ligando-se a um estado estrangeiro ou de caráter internacional, aí sim cabe a sua autuação no artigo 2 da Lei 1.802 , que seria um crime de competência da Justiça Militar (Villas Boas, HC 41.879, julgado pelo STF em 17 de março de 1965).

Os votos dos ministros favoráveis a concessão do habeas foram no mesmo sentido, de que o ato cometido pelo impetrante não configurava crime contra a segurança nacional, razão pela qual não poderia ser julgado pela Justiça Militar. A exceção ao debate em torno da tipicidade das condutas como criminosas foi a posição do ministro Gonçalves de Oliveira, que alegou que

Segurança externa do Brasil é uma balela. Sou contra essas mentiras oficiais. Dou pela competência do tribunal. Fala-se em segurança externa, estamos em guerra com algum país? Ora, essa mentira oficial todo mundo conhece ${ }^{7}$ (Gonçalves de Oliveira, HC 41.879, julgado pelo STF em 17 de março de 1965).

Otavio Valério cita em sua dissertação diversos habeas julgados no período anterior ao AI-2. NO HC 42.159, por exemplo, um padre foi acusado de

distanciar-se da tradição de sua Igreja, que prega a compreensão e a paz entre os homens, passando a integrar e ajudar o Partido Comunista, pelo qual incitava diretamente, de animo deliberado, as classes operarias e camponesas a luta pela violência contra os patrões, no mesmo diapasão dos indivíduos Leonel Brizola e

\footnotetext{
${ }^{7}$ Fala do Ministro Gonçalves de Oliveira, página 13 do HC 41.879.
} 
Joao Goulart, que, diabolicamente, desejavam lavar o solo brasileiro com sangue do seu povo (Valério, 2010, p. 94).

Já no HC 42.120, o acusado era um líder estudantil "responsável pela propagação de ideias subversivas e que possuía em sua casa, além de materiais subversivos, uma bandeira de Cuba" (Valério, 2010, p. 94).

A partir da análise das decisões acima citadas, é compreensível que o entendimento do STF tenha desagradado a linha dura dos militares. Vários habeas foram concedidos por falta de justa causa ou inépcia da denúncia. Contudo, é necessário reforçar que a Corte jamais se rebelou contra a proibição de apreciação judicial dos atos "revolucionários" contidos nos atos institucionais, jamais questionou a constitucionalidade dos mesmos e tampouco se manifestou formalmente sobre as denúncias de tortura e abusos cometidos contra presos políticos. Mesmo após a edição do AI-2, com o aumento do número de ministros - uma clara intervenção do Executivo no Judiciário - a Corte se manteve no papel de legitimadora do regime. Exemplo disso foi o julgamento do HC 42.730, o primeiro julgamento relativo a crimes políticos após o AI-2, quando, por unanimidade, decidiu prejudicado o pedido em razão da incidência da referida norma, o que demonstra que a Corte reconhecia a força normativa de um ato institucional sem questiona-lo, alterando de maneira radical sua jurisprudência anterior (Valério, 2010, p. 116).

É necessário analisar como a limitada atuação do Supremo como barreira de contenção aos arbítrios do regime representou, na visão dos militares, um excesso de atuação judicial. O AI-2 alterou um dos fundamentos utilizados até então (sobre a competência da Justiça Militar e a tipicidade da conduta) mas não alterou o entendimento a respeito do excesso de prazo processual, o que significou, em termos concretos, que o STF continuou a conceder habeas que desagradavam os militares. O último habeas concedido pela Corte em 10 de dezembro de 1968 (apenas três dias antes da promulgação do AI-5), foi em favor de dezenas de estudantes presos durante o congresso de Ibiúna, organizado pela União Nacional de Estudantes (UNE), exatamente com fundamento no excesso do prazo de prisão (Valério, 2010, p. 172).

O Ato Institucional n. 5 e a suspensão total da garantia de habeas corpus nos casos envolvendo crimes políticos atingiu em cheio a Corte Suprema. Suspensa essa garantia, nos anos seguintes o STF continuou se manifestando em recursos ordinários criminais, mas em uma quantidade muito menor do que no período anterior. De acordo com pesquisa conduzida por Swensson Junior:

Durante o regime militar de 1964, o STF julgou 292 recursos ordinários criminais relativos a 565 réus - a grande maioria, recursos apresentados pelos acusados contra decisões que lhes eram desfavoráveis -, negando provimento a 376 réus, na maior parte das vezes por unanimidade. No período entre 1969 e 1974, foram 127 os recursos e 222 réus; no período de 1975 a 1979, 143 recursos e 312 réus (Swensson Junior, 2006, p. 134).

Como bem relata Valério, ainda durante o governo de Castello Branco, em tese um militar mais moderado do que outros enquadrados na denominada linha dura, a opção foi pelo aumento dos ministros e não pela exoneração daqueles considerados opositores à ditadura. Seu predecessor, Costa e Silva, foi mais incisivo e retirou da Corte três ministros quando da edição do AI-5 (Evandro 
Lins e Silva, Hermes Lima e Victor Nunes Leal, ao que seguiu a saída voluntária do então presidente do tribunal, Antônio Gonçalves de Oliveira, bem como do ministro Antônio Carlos Lafayette de Andrada). No final de 1968, os últimos ministros indicados por presidentes civis tinham sido afastados e em 1969, não sobrara nenhum que havia iniciado o ano judiciário de 1964 (Valério, 2010, p. 159). O processo de reforma no Judiciário foi concluído com a edição do AI-6, em $1^{\circ}$ de fevereiro de 1969, que modificou a composição do STF, o qual voltou a ser constituído por 11 ministros. Redefiniu também a competência da Justiça Militar ${ }^{8}$ e manteve em vigor todas as emendas constitucionais produzidas por atos complementares subsequentes ao AI-5.

A Corte Suprema brasileira teve, portanto, três tipos de atitude após o golpe e durante os primeiros anos da ditadura: em um primeiro momento se omitiu e não conheceu pedidos de habeas corpus em que a autoridade coatora fosse militar; depois, passou a conhecer os HC e concede-los. Por fim, após a promulgação do AI-5, quando não pode mais atuar, foi reduzido à ator secundário e quando provocado, se declarava incompetente.

É necessário apontar, contudo, que embora atingido diretamente pela quebra na separação de poderes, decorrente da concentração e centralização focada no Executivo, a mais alta instância do Judiciário brasileiro não foi uma "vítima" do regime. Nesse sentido, Oscar Vilhena Vieira aponta que o período da transição é um período marcado por um grande silêncio por parte do Supremo e dos tribunais em geral, que deveriam, teoricamente, trabalhar visando a reconstrução do Estado de Direito e da democracia. Uma vez revogados os atos institucionais e demais amarras institucionais, seria de se esperar uma atuação forte e incisiva por parte do Judiciário. Entretanto, isso não ocorreu. Conforme aponta o autor:

Para compreender essa questão, leve-se em conta que houve no Poder Judiciário, assim como nos diversos outros setores do sistema político brasileiro, um elevado nível de continuidade do quadro de pessoal que chegou ao poder no período militar, o que contribuiu para uma certa lentidão no processo de transição do antigo para o novo regime, como nos mostra O'Donnell. Como decorrência das relações de confiança alcançadas pelo Supremo junto aos governos militares, alguns de seus ministros foram chamados a colaborar com a reforma judiciária implantada em 1977. Através dessa reforma, foi entregue ao Supremo, por intermédio da Emenda Constitucional n. 7, a competência para "julgar as causas processadas perante quaisquer juízos ou tribunais, cuja avocação deferir, a pedido do Procurador Geral da República, quando decorrer imediato perigo e lesão à ordem, à saúde, à segurança ou às finanças públicas, para que se suspendam os efeitos de decisão proferida e para que o conhecido integral da lide lhe seja devolvido". Foi estabelecida, com a participação decisiva do Procurador Geral da República, a possibilidade de o Supremo avocar para si todos aqueles casos que poderiam suscitar qualquer descontrole na condução do processo de transição (Vieira, 2002, p. 41).

\footnotetext{
${ }^{8}$ Após os Atos 2 e 5, a Justiça Militar passou a ocupar o papel principal na construção jurídico-legal da ditadura, ganhando papel de destaque. pois ampliou formalmente suas atribuições, passando a ser de sua competência o processamento e julgamentos dos recursos em crimes contra a segurança militar e instituições militares, se tornando, em consequência, na retaguarda judicial para a burocracia e a repressão, mostrando-se conivente ou omissa em relação às graves violações aos direitos humanos.
} 
A estrutura do Supremo foi mantida pela Constituição de 1988. Suas atribuições foram ampliadas, redefinindo o papel do Tribunal no sistema constitucional e político do país. Com a ampliação de novos atores legitimados para apresentar ações de inconstitucionalidade, surgiu um novo campo de conflitos constitucionais, onde os tribunais necessitam intervir A Constituição manteve também a formação estabelecida no AI-6, mantendo-se, assim, o número de 11 integrantes, escolhidos entre cidadãos com mais de trinta e cinco anos e menos de sessenta e cinco anos, com "notável saber jurídico e reputação ilibada", nomeados pelo Presidente da República.

\section{Corte Suprema de Justicia de la Nación Argentina: entre a omissão e a ratificação das práticas de terrorismo de Estado (1976-1983)}

\subsection{O ordenamento jurídico e a configuração da Corte Suprema na consolidação da ditadura argentina}

Assim como nos demais países do Cone Sul, a ditadura argentina (1976-1983) não se propôs a modificar por completo o sistema jurídico, mas sim efetuar alterações específicas necessárias para o exercício do poder. Diferente do caso brasileiro, a Constituição argentina foi mantida - pelo menos de um ponto de vista formal - durante todo o período, mas a ordem constitucional foi atingida de modo drástico, através da promulgação de actas, estatutos e leis ${ }^{9}$.

Em 24 de março de 1976, o Palácio de Justiça foi ocupado por efetivos da Aeronáutica e os juízes da Corte Suprema de Justicia de la Nación Argentina foram substituídos por outros nomeados pela Junta Militar. A Acta para el Proceso de Reorganización Nacional, publicada no mesmo dia, determinou a remoção imediata de todos os membros da Corte Suprema, do Procurador-Geral da Nação e dos integrantes dos tribunais superiores das províncias. Os demais juízes nacionais foram declarados inamovíveis "desde sua nomeação ou confirmação" pela Junta. Todos os magistrados que desempenharam seus cargos durante a ditadura deviam prestar juramento para o exercício de suas funções, em primeiro lugar sobre as Actas e em segundo lugar, sobre a Constituição Nacional.

Apenas cinco dias depois, em 29 de março, a Junta emitiu o Estatuto para el Proceso, que estabeleceu que a Junta Militar exerceria as funções do Poder Executivo e, com algumas restrições, do Legislativo. Quanto ao Judiciário, reiterou a remoção imediata dos membros da Corte Suprema e dos tribunais provinciais, determinando, em seu artigo 9, que as novas nomeações fossem realizadas pela Junta e encaminhadas para sanção do Presidente da Nação.

Segundo Juán González Bertomeu (Bertomeu, 2015, p. 94/95), a seleção ficou nas mãos da Força Aérea, que ficara responsável pelo Ministério da Justiça ${ }^{10}$. Com o auxilio do Colegio de Abogados de la Ciudad de Buenos Aires, foi elaborada uma lista com indicados de perfil técnico e longa carreira no Judiciário. Em 02 de abril, os novos integrantes da Corte tomaram posse: Adolfo Gabrielli, Horacio Heredia, Abelardo Francisco Rossi, Alejandro Caride e Federico Videla Escalada. Ao longo dos sete anos de ditadura, a composição da Corte foi modificada. Ao todo, doze juízes

\footnotetext{
${ }^{9}$ Para uma análise mais aprofundada sobre o uso do direito pela ditadura argentina, o capítulo El derecho durante el "Proceso", de Enrique Groisman, aponta as características essenciais das normas emitidas durante o período (Actas, Estatutos, Leyes), mostrando suas contradições e incoerências (Groisman, 2015).

${ }^{10}$ Após o golpe, os ministérios foram divididos entre as três Forças.
} 
ocuparam a posição: cinco deles renunciaram (apenas um por motivação política, o juiz Pedro Jose Frías, que teve um sobrinho desaparecido) e dois morreram (Horacio Heredia e Cesar Black).

A conduta da Corte Suprema durante os anos da ditadura pode ser explicada por sua nova composição. Como bem aponta Bohoslavsky e Gargarella, em artigo que analisa a arquitetura jurídica e institucional do tribunal superior argentino, a ideologia durante aqueles anos se encaixava com o pensamento conservador que recorre a história política e jurídica do país. Segundo os autores:

Trata-se do pensamento marcado pelos ideais da "cruz e espada", que constitui um dos principais nutrientes teóricos da região, desde os anos da independência, nos tempos em que a Igreja e o Exército eram os dois pilares básicos da organização nacional e regional. No que diz respeito à justiça argentina, não é de surpreender que, historicamente, uma maioria de seus membros tenha professado ou professe uma ideologia conservadora ou liberal-conservadora. Essa ideologia se caracteriza, em grande parte, por uma convicção de raiz elitista baseada na desconfiança às capacidades políticas das maiorias e, por outro lado, por uma convicção perfeccionista baseada na ideia de que certas concepções do bem devem ser afastadas em favor de outras avaliadas pelos poderes do Estado (normalmente, isso implica na aplicação de concepções de bem vinculadas com a doutrina do catolicismo). Ambas posturas - elitismo político, em sua versão autoritária, e o perfeccionismo moral, em sua versão religiosa - contam com um amplo respaldo na história judicial argentina) (Bohoslavsky e Gargarella, 2015, p. 79, tradução minha).

Importante ponto que deve ser levado em conta quando se analisa o comportamento da Corte Suprema diz respeito ao que muitos autores argentinos denominam doctrina de facto (ou positivismo jurídico ou ainda, como denomina o jurista Carlos Nino, positivismo ideológico) elaborada pelo tribunal para avaliar os sucessivos golpes ocorridos no país ${ }^{11}$. Essa doutrina sustenta que o direito deve ser obedecido porque está em vigência, respaldado pela força do poder. A justiça ou injustiça intrínseca dessas normas, ou sua origem democrática, se tornam irrelevantes para discutir sua validade. Levando estes fatores em consideração, não é de surpreender uma das primeiras manifestações emitidas pela Corte:

Considerando que um verdadeiro estado de necessidade reinante no país obrigou as Forças Armadas a tomar o Governo da Nação, o dever de proteger os direitos individuais não foi esquecido. Nesse sentido, foram fixados os propósitos e os objetivos básicos para o "Processo de Reorganização Nacional", que se sustenta na Ata que leva a data de 24 de março, jurando cumprir e fazer cumprir esses objetivos, o "Estatuto para o Processo de Reorganização Nacional”e a Constituição Argentina (Bohoslavsky e Gargarella, 2015, p. 81, tradução minha).

Os autores analisam a jurisprudência da Corte desde 1930 no que diz respeito ao reconhecimento de autoridades politicas irregulares e legislação de facto, apontando para a

\footnotetext{
${ }^{11}$ O século XX foi marcado por sucessivos golpes miliares na Argentina: em 1930, 1943, 1955, 19621966 e 1976.
} 
evidência de que, por diversas vezes, usurpações do poder democrático foram convalidados pela Corte (os casos mais emblemáticos seriam a "benção" jurídica da Corte aos golpes de 1930 e 1966). A principal diferença da experiência de 1976 é que os juízes foram empossados apenas dias após o golpe, portanto não era de se esperar que os magistrados escolhidos pelos militares atuassem de maneira contrária aos interesses do novo governo.

A fonte jurídica da nova autoridade politico-militar derivava, segundo a Junta Militar, do direito da nação a "resistir à ameaça de sua própria existência". Este estado de exceção foi positivado e constituiu-se em argumento utilizado para sustentar o ordenamento jurídico da ditadura, que subordinou a Constituição à vontade das Forças Armadas, o que foi referendado pela jurisprudência nacional. A Corte Suprema estabeleceu abertamente que as Atas Institucionais e o Estatuto do Proceso eram normas que integrariam a Constituição enquanto subsistissem as causas que haviam dado legitimidade a essas normas de facto. Essa situação também foi invocada para justificar a extensão do estado de sítio, a confirmação da justiça militar para julgar civis, a suspensão do direito de sair do país e a lesão do devido processo, entre outras garantias constitucionais (Bohoslavsky e Gargarella, 2015, p. 26).

Um fator importante de ser analisado no caso argentino, quando comparado com o Brasil e outros países da região, que mantiveram a maior parte do aparato judicial de tempos de paz durante as ditaduras e o utilizaram para processar dissidentes políticos, na Argentina a opção foi pelo que Mignone e McDonnell denominam Paralelismo Global (Mignone e Mcdonnel, 2006), a face clandestina do Estado que promove o Terrorismo de Estado. Grande parte dos tribunais não se envolvia no regime repressivo exceto para negar pedidos de habeas corpus e para servir como camuflagem do terror estatal.

A Corte Suprema argentina, modificada drasticamente já no dia 24 de março, assumiu, de maneira entusiasmada e eficaz, a função de exercer o controle social e marginalizar opositores, ao mesmo tempo em que dava ao regime um manto de legitimidade, transmitindo a imagem de que a divisão dos poderes e o estado de direito eram respeitados no país. Segundo Bohoslavsky, em matéria de direitos trabalhistas, a Corte Suprema sistematicamente convalidou o cerceamento de direitos individuais e coletivos dos trabalhadores, o que se traduziu em menores custos para o empresariado. No que diz respeito às violações aos direitos fundamentais, seu papel foi além. Tanto a Corte Suprema quanto os tribunais inferiores ratificaram a validade jurídica do Terrorismo de Estado, das normas repressivas ditadas pela Junta, o que teve um impacto devastador para as vítimas e familiares que buscavam no Judiciário algum tipo de auxílio.

Nesse sentido, é importante ressaltar o estudo realizado pelas advogadas Sofia Lanzilotta e Lucia Castro Feijóo, Justicia y Dictadura: Operadores del plan cívico-militar en Argentina, no qual analisam a atuação (ou omissão) dos magistrados (Lanzilotta e Feijóo, 2014, p. 27). A maioria dos juízes argentinos se adaptaram à ordem normativa vigente (a "legalidade" visível e a ilegalidade sobreposta) e com isso, se omitiram de desempenhar sua função de velar pelas garantias, pelos direitos humanos e pelo tratamento digno aos presos ${ }^{12}$. Entre 1976 e 1979, foram apresentados, apenas na Capital Federal, 5.487 habeas corpus, e entre 1980 e 1982, 2.848 (Lanzilotta e Feijóo, 2014, p. 50) e o trâmite era praticamente o mesmo: os juízes recebiam o recurso e faziam despachos (notas de requerimento oficiais) direcionados aos organismos de segurança, consultando se a pessoa

\footnotetext{
${ }^{12}$ Para as autoras, a omissão dos magistrados constituiria, dentro dos marcos hoje estabelecido nos julgamentos que ocorrem na Argentina, um delito por omissão de lesa humanidade.
} 
desaparecida constava em alguma instalação de sua jurisdição. $\mathrm{Na}$ grande maioria dos casos, a resposta era que não havia registros de detenção daquelas pessoas. Após essa posição oficial, o processo era encaminhado para a Promotoria e às partes, tendo como fim sentenças que ratificavam a ausência de registro de que aquela pessoa estava legalmente detida. Assim, com a racionalização teórica e normativa, travestida sob um manto de pseudo-legalidade, o TDE burocratizava a figura do desaparecimento.

Em matéria de habeas corpus, o papel cúmplice da Corte foi extenso e representava a última instância legal a qual podiam recorrer os familiares dos desaparecidos e presos políticos. Segundo Boholavsky e Gargarella:

Quando a Corte decidiu analisar os pedidos dos familiares das vítimas, na maioria dos casos considerou que as detenções eram "razoáveis", já que as causas dessas prisões estariam conectadas aos motivos que levaram à declaração do estado de sitio, como afirmado pelo próprio Poder Executivo, o que significava, em última instância, que não eram analisadas a veracidade do conteúdo desses informes. A Corte não realizou inspeções aos centros de detenção clandestina (denunciados em diversas causas), e não investigou os fatos apontados nos informes produzidos pelo Poder Executivo. Em numerosos casos nos quais os tribunais inferiores exerciam um controle de razoabilidade sobre as prisões de pessoas e rechaçavam as respostas genéricas e infundadas do Poder Executivo, chegando a conclusão de que os detidos deviam ser liberadas, a Corte revogou tais decisões, ratificando a afirmação formulada pelo governo, que apontavam os vínculos dos detidos com atividades subversivas, o que obrigaria os juízes a respeitar a esfera reservada ao poder politico (Bohoslavsky e Gargarella, 2015, p. 86, tradução minha).

Em abril de 1977, chega à Corte o caso Pérez de Smith, no qual um grupo de particulares solicitou a intervenção da Corte alegando que a sistemática negativa das autoridades como única resposta aos recursos de habeas corpus impetrados configurava uma situação de privação de justiça. O Tribunal reconheceu a existência dessa privação, mas ressalvou que os magistrados não tinham condições de reparar a situação e requereu ao Poder Executivo que adotasse as medidas necessárias (não especificando quais seriam essas medidas):

7) Considerando que a privação de justiça antes mencionada obedece a causas alheias às funções e competências especificas dos magistrados, que não estão em condições de remedia-las por sua mera atividade jurisdicional, esta Corte considera um dever inexcusável levar a demanda ao conhecimento do Poder Executivo Nacional e exortar que tomem as medidas necessárias a seu alcance, a fim de criar as condições requeridas para que o Poder Judiciário possa levar a cabo a decisão das causas que lhe são submetidas, salvaguardando a liberdade individual garantida pela Constituição Nacional, sem que isso importe, desde logo, preterir os objetivos da união nacional, paz interior e defesa comum, perseguidos também pela vontade constituinte, que não pode ser desviada pelo poder constituído (Corte Suprema de la Nación Argentina, 1977a, p. 1287, tradução minha). 
O grau de eficácia dessa decisão, evidentemente, foi nulo. Contudo, ainda que de maneira limitada, a Corte deu um primeiro passo no sentido de reconhecer a existência de desaparecimentos forçados, algo que, nesse momento, já era impossível de ser negado, tendo em vista as diversas denúncias internacionais feitas contra a ditadura (Pascual, 2004, p. 113-116).

Até o começo de 1978, a Corte rechaçou todos os casos e convalidou a suspensão, decretada pelo Executivo, do direito de sair do país, previsto no artigo 23 da Constituição ${ }^{13}$. Em julho de 1978, a Corte se pronunciaria em um dos casos mais emblemáticos sobre o tema, o caso Timerman (fallo 300: 816). Jacobo Timerman era um jornalista russo naturalizado argentino, fundador do jornal $\mathrm{La}$ Opinión, de Buenos Aires. Foi sequestrado em abril de 1977 em sua casa, em decorrência de investigações contra seu sócio, Davi Graiver, acusado pela Junta de pertencer à organização de luta armada Montoneros. A Corte considerou que sua prisão era baseada em fatos genéricos e que sua prisão com base no Decreto 1093/77 não se sustentava, motivo pelo qual foi concedido o habeas para sua liberação. Importante destacar a seguinte parte da decisão:

6) Entrando no mérito da questão, dentro dos limites expostos, e observando os princípios jurisprudenciais, a aplicação concreta das faculdades de exceção do poder político devem sujeitar-se ao controle de razoabilidade na adequação de causa e do grau da restrição imposta - a liberdade pessoal, no caso dos autos - e os motivos da situação de exceção. O Decreto 1093/77 determinou a prisão de Jacobo Timerman por "direta e estreita relação com as causas que motivaram a declaração do estado de sitio", expressão genérica que em casos anteriores obrigaram o tribunal a pedir informação mais concreta ao Poder Executivo, que respondeu que considerava os detidos vinculados a atividades subversivas, atividades estas que teriam motivado a declaração do estado de sitio. No presente caso, não se expressou análoga afirmação, sendo que a única sustentação da prisão ordenada no Decreto 1093/77 resulta, segundo o Informe de fls. 71, "do pedido do Comandante em Chefe do Exército, em relação à investigação do caso Graiver, motivo pelo qual estava à disposição do Conselho Especial de Guerra". À fl. 78 foi anexado um informe segundo o qual o cidadão Jacobo Timerman deixou de estar à disposição do Conselho de Guerra Especial n. 2, o que torna inexistente a única motivação concreta que sustentava a prisão com base no artigo 23 da Constituição Nacional. Frente a esta situação, e levando em conta a limitação de pronunciamento referida no Considerado 5, que impede valorar tudo relativo a citada resolução da Junta Militar, não parece razoável reconhecer que subsista adequação de causa entre o estado de sitio e a detenção contra a qual se impetrou o habeas corpus, isso é, a

\footnotetext{
${ }^{13}$ O Estatuto de suspensão do direito de opção de sair do país, sancionado no dia do golpe do Estado, deixou claro que a ditadura não desejava o exílio de opositores políticos. O Estatuto deixava de aplicar o artigo 23 da Constituição na parte que este autorizava as pessoas detidas pelo Poder Executivo a optar sair do país. Justificava-se a medida no risco que significaria conceder a saída do país a pessoas que podiam continuar desenvolvendo atividades subversivas no exterior. Alejandra Pascual analisa o caso de Maria Cristina Ercoli, presa em dezembro de 1975, manifestara sua opção de sair do país. Contudo, quando do golpe, seu pedido não havia sido analisado. Foi impetrado, então, habeas corpus e o juiz de primeira instância e a Câmara de Apelações, determinaram que o Executivo liberasse sua saída. A decisão não foi executada e o caso parou na Corte Suprema, que decidiu que a legislação vigente não era arbitrária "dado o verdadeiro estado de necessidade" pelo qual atravessava o país. Essa e outras decisões conferiram às Juntas Militares a faculdade de ditar penas sem respeitar as garantias do devido processo legal nem o princípio da irretroatividade da lei penal (Pascual, 2004, p. 122-124).
} 
disposição do Decreto 1093/77 (Corte Suprema de la Nación Argentina, 1977b, p. 821-822, tradução minha).

A partir de 1979, gradualmente surgiram fallos que exigiam que juízes de instâncias inferiores investigassem os paradeiros dos desaparecidos. A partir do caso Moya (fallo 303: 696), de 1981, a Corte Suprema começou a considerar inaceitáveis detenções que se estendiam por anos e passou a ordenar ao Executivo que decidisse entre possibilitar a saída do pais ou submete-la a um regime de liberdade vigiada ou prisão domiciliar (Bertomeu, 2015, p. 104).

Foi no final da ditadura, portanto, que a Corte Suprema foi impondo limites graduais ao Executivo. Inicialmente exigia aos juízes que indagassem mais sobre o paradeiro dos desaparecidos; posteriormente, passou a exigir do Executivo medidas mais enérgicas sobre as prisões prolongadas bem como sobre investigações acerca dos desaparecidos. Isso se explicaria, segundo Bertomeu, por fatores como a pressão internacional (intensificada após a visita da Comissão Interamericana de Direitos Humanos em 197914) e pelo fato de que a denominada "luta contra a subversão" já estaria ganha no final da década de 70, uma vez que a maioria dos considerados "subversivos" já teriam sido eliminados. Essas pequenas limitações impostas pela Corte em realidade ajudaram a cobrir com um véu de legalidade e legitimidade os atos da Junta, uma vez que seus atos não tinham grandes impactos reais, como bem aponta Bertomeu:

No momento em que o tribunal superior ditou essas sentenças, a ditadura provavelmente já havia assassinado a maioria dos sequestrados, e nesse sentido, a intervenção judicial não podia ser muito significativa (Bertomeu, 2015, p. 107, tradução minha).

Portanto, nesse caminho radical, a ditadura argentina contou, além do aparato extrajudicial, montado para aplicar a metodologia do Terrorismo de Estado, com facilitadores no mundo judicial. A cumplicidade de juízes, promotores, advogados e funcionários judiciais começariam a ser questionada logo após o fim da ditadura, sendo citada no relatório da CONADEP em 1984 e dando início a um primeiro estágio de mudanças levadas a cabo após a redemocratização, já no chamado Juicio de las Juntas, em 1985.

A Corte Suprema de la Justicia sofreu diversas modificações desde então. A renovação da Corte durante os dois primeiros anos do governo de Néstor Kirchner possibilitou maior independência ao Poder Judiciário e equilíbrio da Corte, tanto ideologicamente quanto por gênero: durante praticamente toda sua existência, os juízes eram homens, católicos e conservadores, quadro que mudou na segunda metade dos anos 2000, quando foram indicadas Elena Highton de Nolasco e Carmem Argibay, esta última defensora dos direitos das mulheres, como o aborto ${ }^{15}$. A modificação

\footnotetext{
${ }^{14}$ A Comissão Interamericana de Direitos Humanos (CIDH), da OEA, visitou o país para aferir as denúncias sobre violações sistemáticas aos direitos humanos, após ter recebido centenas de denúncias de desaparecimentos e impulsionada por setores do governo estadunidense (que, por motivos que não cabe aqui analisar, teve uma mudança considerável em sua política externa a partir da presidência de James Carter). Em setembro de 1979, membros da CIDH entrevistaram autoridades militares, membros de entidades religiosas, organismos de direitos humanos, dirigentes políticos, empresários, jornalistas e ex-presidentes. Também inspecionou dependências militares e policiais, como a ESMA, Coordinación Federal e La Rivera, em Córdoba, denunciadas como Centros de Detenção Clandestinos.

${ }^{15}$ Outra importante indicação foi a de Eugenio Zaffaroni (o primeiro a ser designado mediante um processo público de nomeação), um dos maiores penalistas da América Latina.
} 
na Corte foi vital para as mudanças de paradigmas que viriam, com o julgamento de casos que afastaram as leis de impunidade aprovadas após o fim da ditadura e que possibilitam a ocorrência de julgamentos de crimes de lesa humanidade ${ }^{16}$.

\section{Considerações finais}

Em um estado de direito caracterizado pela separação de poderes e sistema de pesos e contrapesos, as funções exercidas pelo Judiciário seriam três: 1) o controle legal dos atos do poder Executivo e Legislativo; 2) a legitimação das atividades e do próprio funcionamento destes dois poderes e 3) o controle social e solução de conflitos interindividuais na esfera civil, administrativa e criminal (Lanzilotta e Feijóo, 2014, p. 50). Portanto, a autonomia e independência deveriam garantir às instituições de justiça e a seus membros uma condição política diferenciada em relação às demais esferas públicas, garantia voltada à proteção frente a arbitrariedades do controle estatal. Contudo, as Cortes Supremas de Brasil e Argentina não se mantiveram independentes e autônomas ao longo dos períodos analisados.

Brasil, apesar do apoio expresso da maioria dos ministros ao golpe de abril de 1964, pelo menos três magistrados que possuíam alinhamento com presidentes anteriores permaneceram no cargo e atuaram de maneira relativamente independente nos primeiros anos da ditadura. Entre 1964 e 1968, antes da competência dos crimes contra a segurança nacional passarem para a Justiça Militar, o Supremo Tribunal Federal desenvolveu jurisprudência importante que impôs limitação (mesmo que restrita) ao arbítrio da repressão. Apesar desse importante papel, o STF jamais se rebelou contra a proibição de apreciação judicial de condutas previstas nos atos institucionais, jamais questionou a constitucionalidade dos mesmos e tampouco se manifestou formalmente sobre as denúncias de tortura e abusos cometidos contra presos políticos.

A Argentina, por sua vez, recorreu à medidas mais drásticas já no dia do golpe, em 24 de março de 1976. Um dos primeiros atos da Junta Militar foi a substituição de todos os ministros da Corte Suprema por juízes alinhados ao novo regime. A atuação omissa do tribunal superior, que negava sistematicamente habeas corpus, principalmente nos primeiros anos da ditadura, ajudou a concretizar os planos de eliminação física da dissidência, levado a cabo pelas Juntas Militares ${ }^{17}$. A partir de 1978, a Corte passou a exercer um papel menos passivo, impondo certos limites à ditadura, mas como a maioria dos desaparecidos não passou pela repressão legal, podemos afirmar que a atuação da Corte foi débil, pois não coibiu de maneira efetiva as graves violações aos direitos humanos perpetradas ao longo dos sete anos que durou a última ditadura cívico-militar.

A partir da análise da legislação e das fontes, verifica-se que o Supremo Tribunal Federal exerceu um papel mais eficaz em limitar a atuação da repressão do que sua congênere argentina. Isso se explica por alguns motivos: os mecanismos repressivos adotados pelas ditaduras foram diferentes. Na Argentina, o desaparecimento forçado foi a regra. Em razão disso, a maioria das pessoas consideradas dissidentes foram sequestradas, levadas a campos de detenção clandestinos

\footnotetext{
${ }^{16}$ Sobre os julgamentos de crimes de lesa humanidade na Argentina, ver Machado (2015) e Gallo (2016).

${ }^{17} \mathrm{O}$ que leva muitos juristas e sociólogos a definir o plano de eliminação de opositores políticos ocorrido entre 1976 e 1983 como genocídio. Ver Feierstein (2015).
} 
onde, após tortura, eram assassinados e seus corpos eliminados ${ }^{18}$. No Brasil a prisão e a tortura foram os mecanismos mais utilizados pelos órgãos repressivos, como bem demonstram os números de vítimas expostos pelo Relatório Brasil Nunca Mais e pela $\mathrm{CNV}^{19}$. A obsessão dos militares brasileiros em manter uma suposta aura de legalidade os obrigava a recorrer aos mecanismos legais tradicionais, especialmente através do uso dos inquéritos policiais e do processo penal, o que acabava por possibilitar a atuação do Judiciário. Assim, pode-se compreender que o STF atuou mais do que a Corte Suprema argentina, impondo algumas restrições ao arbítrio dos militares.

Se partirmos da visão de Edward Thompson, segundo a qual o direito e as leis invariavelmente possibilitam que as classes dominadas modifiquem injustiças por vias legais (apesar de seu papel de dominação do status quo), compreende-se que, apesar do uso do direito e do ordenamento jurídico para fins de legitimação dessas ditaduras, recorrer ao Judiciário - em especial às Cortes Supremas - foi um ato de resistência por parte de presos políticos, familiares e advogados que atuaram em seus nomes. O uso intenso do mecanismo do habeas corpus em ambos os países permitiu a imposição de certos limites às normas autoritárias, ao mesmo tempo que hoje, passados tantos anos, constituem importante fonte de análise daquele período. A partir desses processos e expedientes, é possível compreender como se comportaram os ocupantes dos cargos de maior hierarquia do Judiciário de Brasil e Argentina frente às denúncias de violações aos direitos fundamentais de seus cidadãos.

Em síntese, o que podemos verificar ao analisar a relação entre as ditaduras e o uso do direito é que houve interesse pelos regimes em manter certo grau de legalidade em suas condutas. Embora não seja o foco deste artigo, é importante refletir também que o apoio dos membros do Judiciário, em especial dos magistrados das Cortes Supremas, é compatível com o perfil e origem social daqueles que exercem essas funções. Problematizar tais assertivas é vital para compreendermos seus papéis quando do fim das ditaduras e nas democracias que se estabeleceram desde então no continente.

\section{Referências}

ACTA PARA EL PROCESO DE REORGANIZACIÓN NACIONAL [Online]. Disponível em: http://www.bnm.me.gov.ar/giga1/documentos/EL000162.pdf. Acesso em 19 mar. 2019.

ALVES, Maria Helena Moreira. Estado e Oposição no Brasil (1964-1984). Petrópolis: Vozes, 1987.

\footnotetext{
${ }^{18}$ Foram usados mecanismos como simulação de fugas, fuzilamentos, criação de fossas coletivas (as chamados tumbas $\mathrm{NN}$ ) e os voos da morte, mecanismo utilizado em um dos maiores centros de detenção clandestino que funcionou na antiga Escuela de Mecánica de la Armada (ESMA), localizada em uma das principais avenidas de Buenos Aires, onde se estima que 5.000 pessoas foram desaparecidas, a maioria jogadas no Rio da Prata para que seus corpos fossem levados pelo mar.

${ }^{19}$ Os dados retirados do Dossiê Ditadura, desenvolvido pela Comissão de Familiares de Mortos e Desaparecidos Políticos, reiterados pela CNV, demonstram a escala do terror implementado pela ditadura brasileira. Cerca de 50 mil pessoas foram presas somente nos primeiros meses da ditadura; há, pelo menos, 426 mortos e desaparecidos políticos no Brasil (incluindo 30 no exterior); um número desconhecido de mortos em manifestações públicas; 7.367 indiciados e 10.034 atingidos na fase de inquérito, em 707 processos na Justiça Militar por crimes contra a segurança nacional; 4 condenações à pena de morte; 130 banidos; 4.862 cassados; 6.592 militares atingidos; milhares de exilados e centenas de camponeses assassinados e até o momento, 24.560 vítimas de perseguições por motivos políticos foram anistiados.
} 
BAUER, Caroline Silveira. Um estudo comparativo das práticas de desaparecimento nas ditaduras civil-militares argentina e brasileira e a elaboração de políticas de memória em ambos os países. Tese de Doutorado. Universidade Federal do Rio Grande do Sul, 2011.

BERTOMEU, Juán González. Los doce apóstolos. La Corte Suprema y sus jueces en la dictadura. In: BOHOSLAVSKY, Juan Pablo (Org). Usted también Doctor? Complicidad de jueces, fiscales y abogados durante la dictadura. Buenos Aires: Siglo Veintiuno, 2015.

BOHOSLAVSKY, Juan Pablo; GARGARELLA, Roberto. El rol de la Corte Suprema. Aportes repetidos y novedosos. In: BOHOSLAVSKY, Juan Pablo (Org). Usted también Doctor? Complicidad de jueces, fiscales y abogados durante la dictadura. Buenos Aires: Siglo Veintiuno, 2015.

BRASIL. Ato Institucional $n^{\circ}$ 4, de 7 de dezembro de 1966 [Online]. Diário Oficial da União, Poder Executivo, DF, 1966. Disponível em: http://www.planalto.gov.br/ccivil_03/ait/ait-04-66.htm. Acesso em: 19 mar. 2019.

. Ato Institucional $n^{\circ}$ 2, 27 de outubro de 1965 [Online]. Diário Oficial da União, Poder Executivo, DF, 1965. Disponível em: http://www.planalto.gov.br/ccivil_03/AIT/ait-02-65.htm. Acesso em: 19 mar. 2019.

. Ato Institucional $n^{\circ} 1$, de 9 de abril de 1964. Diário Oficial da União, Poder Executivo, DF, 1964. Disponível em: http://www.planalto.gov.br/ccivil_03/AIT/ait-01-64.htm. Acesso em: 19 mar. 2019.

COMISSÃO NACIONAL DA VERDADE. Capítulo 17 - O Judiciário na ditadura [Online]. Disponível em:

http://cnv.memoriasreveladas.gov.br/images/documentos/Capitulo17/Capitulo\%2017.pdf. Acesso em: 19 fev. 2018.

CORTE SUPREMA DE LA NACIÓN ARGENTINA. Fallos de La Corte Suprema. Fallo 297: 338 (Peréz Smith) [Online]. 1977a Disponível em:

http://constitucion.webcindario.com/fallos/perezdesmith.pdf. Acesso em: 10 mar. 2019.

. Fallos de La Corte Suprema. Fallo 300: 816 (Timerman) [Online]. 1977b. Disponível em: http://constitucion.webcindario.com/fallos/timerman1978.pdf. Acesso em: 10 mar. 2019.

ESTATUTO PARA EL PROCESO DE REORGANIZACIÓN NACIONAL [Online]. Disponível em: http://www.bnm.me.gov.ar/giga1/documentos/EL000162.pdf. Acesso em: 19 mar. 2019.

FEIERSTEIN, Daniel. Juicios. Sobre la elaboración del genocidio. Buenos Aires: Fondo de Cultura Económica, 2015.

GALLO, Carlos Artur. A história no banco dos réus. Leis de impunidade, memória da repressão política e as decisões da Suprema Corte na Argentina e no Brasil. Tese de Doutorado. Universidade Federal do Rio Grande do Sul, 2016.

GASPAROTTO, Alessandra. “Companheiros ruralistas!”: mobilização patronal e atuação política da Federação das Associações Rurais do Rio Grande do Sul (1959-1964). Tese de Doutorado. Universidade Federal do Rio Grande do Sul, 2016.

GROISMAN, Enrique. El derecho durante el "Proceso". In: BOHOSLAVSKY, Juan Pablo (Org.). Usted también Doctor? Complicidad de jueces, fiscales y abogados durante la dictadura. Buenos Aires: Siglo Veintiuno, 2015.

LANZILOTTA, Sofia; FEIJÓO, Lucía Castro. Justicia y Dictadura: Operadores del plan cívicomilitar en Argentina. Buenos Aires: Ediciones del CCC, 2014. 
MACHADO, Patricia da Costa. As Supremas Cortes de Brasil e Argentina frente aos crimes de lesa humanidade perpetrados pelas ditaduras. Dissertação de Mestrado. Universidade Federal do Rio Grande do Sul, 2015.

MIGNONE, Emilio F; MCDONNELL, Augusto C. Estrategia represiva de la ditadura militar: la doctrina del "paralelismo global". Buenos Aires: Colihue, 2006.

PADRÓS, Enrique Serra. Como El Uruguay no hay...Terror de Estado e Segurança Nacional Uruguai (1965-1985): do Pachecato à ditadura civil-militar. Tese de Doutorado. Universidade Federal do Rio Grande do Sul, 2005.

PASCUAL, Alejandra Leonor. Terrorismo de Estado: a Argentina de 1976 a 1983. Brasília: Editora UnB, 2004.

PEREIRA, Anthony W. Ditadura e repressão: o autoritarismo e o estado de direito no Brasil, Chile e Argentina. São Paulo: Paz e Terra, 2010.

SWENSSON JUNIOR, Walter Cruz. Os limites da liberdade. A atuação do Supremo Tribunal Federal no julgamento de crimes políticos durante o regime militar de 1964 (1964-1979). Tese de Doutorado. Universidade de São Paulo, 2006.

THOMPSON, Edward P. Senhores e Caçadores: a origem da Lei Negra. Rio de Janeiro: Paz e Terra, 1987.

VALÉRIO, Otávio. A toga e a farda: o Supremo Tribunal Federal e o regime militar (1964-1969).

Dissertação de Mestrado. Universidade de São Paulo, 2010.

VIEIRA, Oscar Vilhena. Supremo Tribunal Federal: jurisprudência política. São Paulo: Malheiros Editores, 2002.

VILLAS BOAS, Martins. Arquivo CNV, 00092.000251/2015-05: HC 41.879, julgado pelo STF em 17 de março de 1965 [Online]. Disponível em:

http://cnv.memoriasreveladas.gov.br/component/content/article/41-documentos-citados-no-volumei-do-relatorio/621-documentos-citados-capitulo-17.html. Acesso em: 10 mar. 2019.

Artigo recebido em: Março/2019

Artigo aprovado em: Julho/2019

Patricia da Costa Machado (patydcm@hotmail.com) é Doutoranda em História pela Universidade Federal do Rio Grande do Sul (UFRGS).

\section{Justiça e Ditadura: atuação das Cortes Supremas de Brasil e Argentina durante as Ditaduras de Segurança Nacional}

Resumo. $\mathrm{O}$ artigo tem como objetivo analisar, através de decisões judiciais e legislação concernente ao papel das Cortes Supremas de Brasil e Argentina, o posicionamento destes tribunais frente à ruptura democrática vivenciada nesses países a partir dos golpes de 1 de abril de 1964 e de 24 de março de 1976, buscando compreender a relação dialética entre o Judiciário e a repressão que foi implementada nos anos que se seguiram. O arcabouço teórico se sustenta na perspectiva da história do direito, um conceito abrangente que inclui regras, normas sociais sancionadas por autoridades, 
dentro de um sistema preciso de coerções e punições e que exige uma delimitação clara de suas fronteiras. A partir da análise da legislação e das fontes, verifica-se que o Supremo Tribunal Federal exerceu um papel mais efetivo em limitar a atuação da repressão do que sua congênere argentina, demonstrando, contudo, o interesse de ambos os regimes em manter certo grau de legalidade em suas condutas.

Palavras-chaves: Ditaduras de Segurança Nacional; Argentina; Brasil; Corte Suprema.

\title{
Justice and Dictatorship: the Argentina's and Brazil's Supreme Courts during the National Security Dictatorships
}

\begin{abstract}
This article aims to analyze, through judicial decisions and legislation concerning the role of the Supreme Courts of Brazil and Argentina, and it's position concerning the democratic rupture experienced in these countries since the coups of April 1 of 1964 and March 24 of 1976, seeking to understand the dialectical relationship between the Judiciary and the repression that was implemented in the years that followed. The theoretical perspective is based on the history of law, a comprehensive concept that includes rules, social norms sanctioned by authorities, within a precise system of coercion and punishment and that requires a clear delimitation of its borders. The analysis of the legislation and the sources allowed to verify that the Brazilian Supreme Court played a more effective role in limiting the repression than its Argentinian counterpart, demonstrating the interest by both of the regimes in maintaining a certain degree of legality in their conduct.
\end{abstract}

Keywords: National Security Dictatorships; Argentina; Brazil; Supreme Court. 